\section{A Combined Model Study: The Needs of Parents of Children with Attention Deficit Disorder with Hyperactivity (ADHD) in Parent Education*}

\author{
Cahit Nurij $^{a,{ }^{* *}}$, Gönül Akçamete ${ }^{b}$, Cemaliye Direktör ${ }^{c}$
}

\begin{tabular}{ll}
\hline Received: & 26 April 2019 \\
Revised: $\quad 19$ August 2019 \\
Accepted: $\quad 05$ September 2019 \\
ISSN: 1307-9298 \\
Copyright @ IEJEE \\
www.iejee.com
\end{tabular}

DOI: 10.26822/iejee.2019155333

\begin{abstract}
ADHD children have some special education needs. Participation of parents in the process plays an essential role in the effectiveness of education. Determination of the educational expectations of parents of children with special status in parent education, which is part of lifelong education, and preparation of education programs in line with these needs are of great importance for the development of the society. The aim of the research in this direction is to determine the educational needs of parents with ADHD children. In addition, determining stress and quality of life constitutes the other sub-objectives of the research. A mixed model is used in the study. Through special education teachers 200 parents (110 mothers and 90 fathers) were reached. "Beach Centre Family Quality of Life Scale", "Perceived Stress Level Scale" and "Tool for Determining Parent Needs" were used for quantitative data. According to the obtained results, the stress level of parents is a significant predictor of quality of life $(\beta=-.204, t=-2.738, p<.01)$. Among these parents, semi-structured interviews were held with 15 volunteers. Case study was conducted for qualitative data. The answers given to the questions in line with the themes formed by the researcher were examined. With qualitative data, it was found that parents felt emotional disability, had negative experiences with the environment, and that the child had difficulty in solving school problems. In addition, when the responses were examined, it was seen that participants often needed practical training $(f=12)$ to solve the problem. When the literature is examined, the research findings are similar to other findings indicating that having a child with ADHD brings some difficulties. Preparation of education programs answering to the needs of parents has been proposed.
\end{abstract}

Keywords: ADHD, Parent, Parent Education, Quality of Life, Stress

\section{Introduction}

Attention Deficit Disorder with Hyperactivity (ADHD) has claimed a place among the important problems of the fields of psychiatry and education for years as a lifelong disorder. ADHD is defined as a neuro-developmental disorder which progresses with lack of attention, hyperactivity and impulsivity (APA, 2013). According to DSM-5 (Diagnostic and Statistical Manual of Mental Disorders, $5^{\text {th }}$ edition) lack of attention and/or hyperactivity/impulsivity in children and adolescents requires the common observation of at least 6 symptoms in at least two different social settings, that they continue in an incompatible manner with development level for at least 6 months, compromise functionality and that these symptoms begin before the age of 12 so that a diagnosis can be made. It is reported that after the age of 17 at least 5 symptoms should be observed in any kind of area (APA, 2013).

Various studies give the prevalence of ADHD in children and adolescents as 5 to $7.1 \%$ and in adults as 2.5 percent (Polanczyk et al., 2007; Simon et al., 2009; Willcutt, 2012; Gallo \& Posner, 2016). Davies (2014) reported that ADHD is observed 2 to 4 times more in girls than boys due to the late diagnosis because of differences in symptoms. Although changes can be observed in the severity and frequency of ADHD symptoms throughout life, it is witnessed that symptoms are mostly apparent in pre-school period (Daley et al., 2009; Ozerk, Handorff, \& Ozerk, 2017) and that they continue in adulthood in ratios up to 50 percent (Spencer et al., 2007; Geissler \& Lesch, 2011).
It is known that the parents of children with behavioral problems suffer more from mental illnesses. Studies show that the frequency of depression in mothers of children with behavioral disorders is 25 percent (Aydın \& Ercan, 2005). In fact, all parents experience the feelings of fear, anxiety, worrisome, panic, anger and fatigue during the development of their children as well as many positive feelings. Parents of children with ADHD live these emotions more intensely (Harpin, 2005; Ozerk, Handorff, \& Ozerk, 2017). Many parents are often at war with children with ADHD because they do not fully understand the nature of this disorder (Senol, Işeri, \& Kockar, 2005). Research shows that the stress levels of parents of children with ADHD are related to the severity of behavioral disorders in children with ADHD. McLaughlin and Harrison (2006) found that the severity of children's destructive behaviors influenced the sense of parental competence and effective parenting behaviors in the negative direction. In addition, in studies comparing the stress levels of families of children with normal development with those of ADHD children, the stress levels of families of ADHD children were found to be higher than those of normal-growing children (Durukan et al., 2008; Johnston \& Mash , 2001).

Problems arise in the harmony with the community of the individual who is faced with stressful situations. As seen in children with ADHD; difficulty in following the guidelines, attention problems such as forgetting or losing homework, focusing on school work, behavioral problems that can be experienced in friend relationships, and impulsive situations that can result in injuries can be a source of stress in their families (McCleary, 2002). In such confrontational situations,

\footnotetext{
*This article was based on Cahit Nuri's Ph.D. Thesis.

${ }^{a, * *}$ Corresponding Author: Cahit Nuri, Department of Special Education, Faculty of Education, Cyprus International University, 99138 Nicosia (via Mersin 10 Turkey), North Cyprus. E-mail: cnuri@ciu.edu.tr

• Gönül Akçamete, Department of Special Education, Faculty of Education, Near East University, 99138 Nicosia (via Mersin 10 Turkey), North Cyprus. E-mail: gonul.akcamete@neu.edu.tr

Cemaliye Direktör, Departman of Psychology, Faculty of Art and Science, European University of Lefke, 99728 Lefke, (via Mersin 10 Turkey), North Cyprus. E-mail: cdirektor@eul.edu.tr 
the individual's harmony with the community is compromised (Terzi \& Cankaya, 2006).

Literature search indicates that the severity of behavioral disorders in children is an important factor for stressful situations. Families of children with ADHD have higher levels of stress than do children of normally developing children (McCleary, 2002). In a study by Xiang, Luk and Lai (2009), the life quality of children with ADHD was found to be lower in the psychological, social, physical, and environmental contexts than the children of normal development children. In addition, many studies have focused on the mothers' stress levels of children with ADHD. Mothers of ADHD children are more likely to be affected psychologically in years than the parents of normally developing children (Fischer, 1990). The notion of "Family Life Quality" deriving from the concept of quality of life is defined as a personal perception of how much satisfaction is achieved by being together with the family (Nuri, Akcamete, \& Direktor, 2019; Park Hoffman, Marquis, Turnbull, Poston, Mannan, Wang, \& Nelson, 2003; Turnbull, Turbiville, \& Turnbull, 2000).

According to Schalock and Verdugo-Alonso (2002), the criterion of the quality of life of an individual is related to his/ her family by nature. The importance of family increases for individuals with special needs (Seltzer, Floyd, \& Hindes, 2004; Nuri, Akcamete, \& Direktor, 2019). Participation of parents in the process is the subject of special education services. This process requires arrangements to determine appropriate services taking into account the needs of both the child and the family. For this effect, it is essential to have data related to the characteristics of the family (Cavkaytar, Batu, Kartal, Cetin, \& Gullupınar, 2004). The type of disability, the grade, the socio-economic level of the parents, the age and the support they receive influence their parents' feelings and behaviors (Aysan \& Ozben, 2007; Nuri, 2017).

ADHD is one of the most important problems of the fields of child psychiatry and child education. Despite the fact that the treatment is easy to answer, the difficulty of both the family and the teachers is increasing the importance of family and teacher education. Ensuring integrity in the effectiveness of special education is of great importance. The family is at the center of this wholeness (Nuri, 2017). While mothers of children with developmental disability indicated that negative impacts, family problems and stress are reduced after family support programs, they also stated that quality of life of the family increased (Feldman \& Werner, 2002). For this reason, ensuring that the members of family reach accurate information in the shortest time possible after the diagnosis is made on the children will make sure that the family becomes more devised in the face of the situation which causes stress.

It is necessary to investigate the problems and needs of the parents when determining what support will be given to their parents (Natale \& Lubniewski, 2018). Studies conducted with parents have been seen to be very limited. In this study, it was aimed to determine the relationship between the quality of life and stress level of parents with ADHD children and the needs of parents in order to contribute to their lives and children. It is thought that it will make a great contribution to the future studies because of the information obtained about the parents with the results to be obtained.

\section{Method}

In order to ensure the validity and reliability of the data combined study model was used which consisted of multiple data collection techniques (Kose, 2010). The purpose here was to examine the education needs of parents of children with ADHD using a combined model which interpreted the results obtained from both qualitative and quantitative data (Johnson \& Christensen, 2008). Relational scanning model was used for quantitative data and case study analysis was used for qualitative data.

\section{Study Group}

The study group of the research consisted of mothers $(n=110)$ and fathers $(n=90)$ of children with ADHD from the Turkish Republic of Northern Cyprus $(n=200)$. The research group was selected based on the purposive sampling method. Semi-structured interviews were held with 15 people who were voluntary.

\section{Data Collection Tools}

\section{Beach Centre Family Quality of Life Scale (BCFQLS)}

BCFQLS was developed by the Kansas University Beach Centre on Disability (Beach Centre on Disability, 2006) (Hoffman, Marquis, Poston, Summers, \& Turnbull, 2006). The adaptation to Turkish, reliability and validity studies of the scale were conducted by Meral and Cavkaytar (2013). BCFQLS provides information on the basis of "satisfaction" and "importance" perception in regard to the entire family quality of life ( 25 questions, Cronbach's alpha $=.94)$ and "Family interaction (6 questions, Cronbach's alpha $=.92)$ ", "Parenting (6 questions, Cronbach's alpha $=.88)$ ", "emotional well-being (4 questions, Cronbach's alpha $=.80$ )", "Physical/material well-being (5 questions, Cronbach's alpha $=.88$ )" and "disability-related support (4 questions, Cronbach's alpha= .92)" (Akın, Abacl, \& Cetin, 2007).

\section{Perceived Stress Scale (PSS)}

The perceived stress scale (PSS) was developed by Cohen, Kamarck and Mermelstein (1983). Higher scores indicate higher levels of stress. In the Turkish adaptation of the scale, the internal consistency coefficient was found as .84 and the test-retest reliability coefficient was reported as .87 (Eskin, Harlak, Demirkıran, \& Dereboy, 2013).

\section{Tool for Determining the Needs of Parents}

It was developed by Bailey and Simeonsson in 1988 with the purpose of determining the needs of parents. Cavkaytar, Ardic and Aksoy (2014), calculated the item-total score correlation and test-retest reliability using all items in order to determine Cronbach alpha coefficient is .91. As a result of the analysis conducted in order to determine the reliability and validity of AGBA, it has been seen that the tool is reliable on the basis of item-total correlation, highest score and test-retest reliability. The tool for determining family needs consists of two sections. In the first section, there are four sub-scales expressing different needs of parents and 29 items in total in these four sub-scales. In the scale, there are 29 items in total: 7 items expressing the need for explaining the community, 10 items expressing need for information, 6 items expressing material needs, and 6 items expressing general support and social service needs. Each item in the first section is answered as Yes (3), Not sure (2) and No (1).

\section{Interview Form}

It is stated that despair, shame, sorrow, anxiety and depressive symptoms are observed among the parents of individuals with special needs (Dalbudak, Evren, Evren, \& Ozen, 2017). The parents of children with ADHD suffer from more stress and feel self-inefficacy as the care requirements of children increase in childhood. As a result, they report more psychopathologies compared to other children (Durukan et al., 2008). In accordance with the ob- 
jective of the study, a semi-structured interview form was prepared consisting of 7 open-ended questions in order to obtain qualitative data so as to identify the problems and difficulties experienced by parents.

Table 1. Family Interview Questions

\begin{tabular}{|c|}
\hline $\begin{array}{l}\text { 1.What are the attention and/or behavioral problems that you } \\
\text { observe in your children which make you sad and uncomfortable? } \\
\text { Why do these behaviors make you sad? }\end{array}$ \\
\hline $\begin{array}{l}\text { 2. How do you react when your child displays lack of attention / } \\
\text { hyperactivity behaviors? }\end{array}$ \\
\hline 2.1 How does your spouse react? \\
\hline $\begin{array}{l}\text { 3.What are the positive behaviors of your child? How do you react } \\
\text { when he/she displays positive behavior? }\end{array}$ \\
\hline $\begin{array}{l}\text { 4.In this process how was your relations, friendship and neighbor- } \\
\text { hood relations affected? What changed in your life? }\end{array}$ \\
\hline $\begin{array}{l}\text { 5.What are the difficulties you experienced related to school (school } \\
\text { life, homework assignments, relations with friends etc.)? }\end{array}$ \\
\hline $\begin{array}{l}\text { 6. Have you ever received education / psychological support for } \\
\text { dealing with the problem of your child? What use was this support? }\end{array}$ \\
\hline $\begin{array}{l}\text { 7.If you have not received any support, what kind of education/sup- } \\
\text { port do you think you need? }\end{array}$ \\
\hline
\end{tabular}

\section{Findings}

The results of the study related to quantitative and qualitative data are provided below in order.

Table 2. Descriptive Statistics for Identifying Requirements

\begin{tabular}{lrrrr}
\hline & Min. & Max. & $M$ & S \\
\hline Material & 6 & 18 & 8.51 & 2.91 \\
\hline Information & 10 & 30 & 22.85 & 5.20 \\
\hline Explaining to the community & 7 & 21 & 11.02 & 3.26 \\
\hline General support-social services & 6 & 18 & 7.87 & 1.85 \\
\hline
\end{tabular}

An examination of the findings related to quantitative data shows that the need with highest frequency of parents is information. When Table 2 is examined, it can be seen that the Information Requirement mean score of parents is high (22.25 \pm 5.20$)$ and Explaining to the community mean scores $(11.02 \pm 3.26)$ is also considerably high. It has been found out that the two other dimensions of measuring tool, namely Material requirements $(8.51 \pm 2.91)$ and General support and Social services $(7.87 \pm 1.85)$ are not needed.

Table 3. Results of multiple regression analysis on the inadequate self-efficacy sub-dimension, which is a sub-dimension of the perceived stress scale

\begin{tabular}{|c|c|c|c|c|c|c|}
\hline Variable & $B$ & $\begin{array}{r}\text { Standard } \\
\text { error }\end{array}$ & $\beta$ & $t$ & $p$ & $\begin{array}{r}\text { Partial } \\
r\end{array}$ \\
\hline (Constant) & 27.987 & 1.287 & & 21.746 & .000 & \\
\hline $\begin{array}{c}\text { Family } \\
\text { interaction }\end{array}$ & -.113 & .068 & -.185 & -1.662 & .098 & -.119 \\
\hline Parenting & -.166 & .069 & -.266 & -2.421 & .016 & -.171 \\
\hline $\begin{array}{l}\text { Emotional } \\
\text { well-being }\end{array}$ & -.192 & .070 & -.204 & -2.738 & .007 & -.193 \\
\hline $\begin{array}{c}\text { Physical/ } \\
\text { material } \\
\text { well-being }\end{array}$ & .048 & .059 & .067 & .809 & .419 & .058 \\
\hline $\begin{array}{l}\text { Disability-re- } \\
\text { lated support }\end{array}$ & .226 & .093 & .201 & 2.433 & .016 & .172 \\
\hline$R=.497, R^{2}=.2$ & Adapte & $R^{2}=.227$ & $94)=1$ & $15, p=$ & & \\
\hline
\end{tabular}

An examination of the analysis results shows that (Table 3) the family interaction, parenting, emotional well-being, physical/material well-being and disability-related support sub-dimensions are predicted with inadequate self-efficacy. $R=.497, R^{2}=.0247, F_{(5,194)}=12.715, p<.001$. It can be expressed that $25 \%$ of the variance related to inadequate self-efficacy is explained by the family quality of life sub-dimensions. Independent examination of the sub-dimensions of family quality of life show that family interaction and physical/material well-being are not significant predictors of inadequate self-efficacy, whereas the emotional well-being $(\beta=-.204, t=-2.738, p<.01)$, parenting $(\beta=-.266, t=-2.421, p>.05)$ and disability-related support $(\beta=.201, t=2.433, p>.05)$ sub-dimensions are predictors of inadequate self-efficacy.

Table 4. Multiple regression results of stress perception

\begin{tabular}{lrrrrrr}
\hline Variable & $B$ & $\begin{array}{r}\text { Standard } \\
\text { error }\end{array}$ & $\beta$ & $t$ & $p$ & $\begin{array}{r}\text { Partial } \\
\text { (Constant) }\end{array}$ \\
\hline $\begin{array}{l}\text { Family } \\
\text { interaction }\end{array}$ & -.402 & .061 & -.590 & -6.632 & .000 & -.430 \\
\hline Parenting & -.046 & .061 & -.066 & -.750 & .454 & -.054 \\
\hline $\begin{array}{l}\text { Emotional } \\
\text { well-being }\end{array}$ & -.252 & .063 & -.240 & -4.027 & .000 & -.278 \\
\hline $\begin{array}{l}\text { Physical/ } \\
\text { material } \\
\text { well-being }\end{array}$ & .080 & .053 & .099 & 1.503 & .134 & .107 \\
\hline $\begin{array}{l}\text { Disability-re- } \\
\text { lated support }\end{array}$ & .246 & .083 & .196 & 2.968 & .003 & .208 \\
\hline \begin{tabular}{l}
$R=.720, R^{2}=.518$, Adapted $R^{2}=.506, F_{(5,194)}=41.717, p=.000$ \\
\hline
\end{tabular}
\end{tabular}

An examination of the multiple regression results concerning stress perception (Table 3), shows that the family interaction, parenting, emotional well-being, physical/material well-being and disability-related support sub-dimensions predicted stress perception together. $R=.720, R^{2}=$ $.518, F_{(5,194)}=41.717, p<.001$. It can be expressed that $52 \%$ of the variance related to stress perception is explained by family quality of life sub-dimensions. Independent examination of the sub-dimensions of family quality of life shows that family interaction $(\beta=-.590, t=-6.632, p<.001)$, emotional well-being $(\beta=-.240, t=-4.027, p<.001)$ and disability-related support $(\beta=.198, t=2.968, p<.01)$ are significant predictors of stress perception, whereas the parenting $(\beta=-.066, t=-.750, p>.05)$ and physical/material well-being ( $\beta=.099, t=1.503, p>.05$ ) sub-dimensions are not predictors of stress perception.

\section{Results Related to Qualitative Data}

In-depth analysis of the problems and needs of parents of children with ADHD is among the objectives of this study. In this line, questions prepared by the researchers were asked to 11 females and 9 males, making a total of 15 people. The results related to the case study analysis are presented.

Case study analysis was conducted for qualitative data. The answers given to the questions were examined in accordance with the themes constructed by the researcher. The obtained data were analyzed using content analysis method. The answers given to the semi-structured questions were used to create meaningful groups and thus categories were formed. The data were coded according to the categories. Some parents displayed more than one code; as a result, frequencies of the categories determined are presented according to the codes of parents. The codings are organized according to the content and presented by making direct citations. The names of participants were held confidential according to ethical principles and letters and numbered were used for codes.

Validity. Data obtained from the participants were written in detail and the manner with which these results are obtained is explained in detail. The opinions of parents interviewed were directly provided so as to ensure validity. 
Reliability. Researchers abstained from directing the interviewees during interviews. In order to ensure the reliability of the coding used in the study, 6 data randomly selected from 15 papers were coded separately by researchers and the reliability between two coders was calculated. The consistency was estimated as 80 percent.

One of the questions prepared by researchers, opinions concerning medicine usage, was examined. In this line, it was found out that interviewees were unwilling to use medicine $(f=4)$ and anxious about the possible harms that can be done to their children $(f=9)$. In addition, it was observed that some participants stated that they used it as they felt obligation and as it provided some benefits $(f=2)$.

A1. "We are personally against medicine. But due to hyperactivity and attention disorder we are giving the medicine due to the recommendation and follow-up of the doctor. As for difficulties, as the case in every medicine, its side effects."

A3. "We fear from the side-effects of the study and are having difficulties in taking it."

A4. "From the very beginning I do not want him to sue the medicine at all. We did not have any difficulty in using it. But I fear from filling with chemical medicine the mechanism of a child at this small age."

A12. "He can do his homework better when he takes medicine. We do not have problems as he uses it during school time. He does not use it during vacations."

An examination of the answers given to the questions on problems experienced at school, being unwilling to do homework $(f=8)$, not being able to study $(f=4)$, negative relations with peers $(f=3)$ and behavior problems $(f=3)$ come to the forefront. One participant stated that he did not have any school problems due to special education support whereas another interviewee stated that he was anxious about his child receiving special education and that his child was not safe.

A5. "Classroom teachers put pressure to ensure that he did not use medicine. In addition, he was subjected to the same education and teaching with his peers. It tired me a lot. I also had difficulty in making him do his homework assignments."

A6. "He did not want to go to school and he could not get on well with his classmates. Due to shyness he did not have any friends."

A8. "He never wants to do homework alone. He does not want to read. I always punish him by confiscating his phone. But it does not work."

A13. "He does not want to do homework. He always yells and shouts. He throws books and notebooks."

Parents were also asked about how they reacted towards the negative behaviors of their children and, as a result, the effect on behavior control as parents. Interviewees stated that they lost their nerves when they witnessed hyperactivity and not listening $(f=13)$. It was observed that some interviewees felt sorry $(f=1)$ and tired $(f=3)$. It has been found out that interviewees felt themselves inadequate in controlling behaviors $(f=15)$.

A2. "His exclusion from the community. I am very sad that he loses his self-confidence. I find it difficult to voice over. He does not listen to anyone but me. Our first method is talking. When we get beyond it, we prefer punishment or depriving him off his favorite things."

A8. "He sometimes jumps on armchairs. I always give him verbal directions like sit down or don't. I get angry. I always give some directions. Then I get angry when they are not followed. For example, when I say leave the phone I have to say it 10 times. I want to have more rest. I am losing my nerves."
A15. "How can I concentrate his attention more? I am tired of his groundless and timeless speeches and unnecessary questions. I am using some methods such as rewarding but I fail."

Their reactions towards the positive behaviors of their children have also been observed. It is determined that interviewees frequently find their sharing behavior positive and reward it $(f=14)$. One interviewee stated that his child did not have any positive attitude.

A7. "He is very well in sharing. He loves sharing. I say, "well done". I appreciate behavior."

A9. "Him knowing to share with his friends. I say, "well done, mummy" and kiss him."

A10. "Not much happened. His not listening is what I complain most. I give both punishment and reward, but I cannot say that it works. I do not know how to solve it."

Mothers attended qualitative study. Fathers were not voluntary for the interview. When asked about the reaction of the spouse, most answers showed that they did not show interest $(f=12)$. In addition, two interviewees said that the father was too authoritarian and gave harsh reactions, whereas one interviewee said that the father had more moderate approaches and was supportive.

A5. "My husband does not give reaction as he does not interest himself much in the child. He acts unlabored."

A8. "My husband does not show much interest. He has a lack of authority in the father."

A11. "Our father is an authority. He usually shouts. He only fears from his father."

A14. "I lose my nerves, but his father is very understanding. He tries to teach what he has to do with the utmost patience. He is also very supportive for me. He takes away lots of load."

Another question was about how the family was affected by ADHD. An examination of the relations with the community showed that almost all had difficulties and problems with the community. One interviewee added financial troubles as well.

A2. "In the beginning my family did not know what kind of disorder this was. I was tired of trying to explain. They thought that my child was naughty. My life became so exhausting. I am having difficulty in sparing time to myself."

A5. "He does not get on well with the kids of the neighbor. I was too affected by the neighbors. I do not go to the neighbors due to the problems of my child. We had financial difficulties. I am feeling exhausted and fatigued spiritually."

A9. "His hyperactivity causes problems. He is labelled as naughty. And this tires me a lot. I do not want to go anywhere."

A13. "My friends did not want to come and visit us. I began to get tired more. I had difficulties in completing my housework."

Finally, the expectations of the interviewees from the education were asked. An examination of the answers given shows that the interviewees frequently needed a practical training aiming at solving problems $(f=12)$. Two of these interviewees demanded a fast education on problem-solving. In addition, some interviewees requested information on ADHD and its process $(f=3)$. Two participants stated that they were open to all kinds of education which would help. One interviewee explained that she needed an education on turning peer relations into positive and eliminating anxieties for the future. 
A2. "I would expect it to be helpful in producing solutions to problems with contemporary methods. I would like to be more knowledgeable on ADHD. I would suffer from indecisiveness concerning school selection."

A6. "I am ready to do whatever is useful for this kind of children."

A8. "How will I rule the roost. I can intervene in how to prevent his childish behaviors. Giving information on how he will communicate with his friends. How will he have a profession. I am anxious on what to do if he goes to secondary school."

A10. "Giving seminar and follow-up to parents. It must be a practical seminar."

A11. "I would prefer a didactic and expert education on how to answer all problems experienced until today. A team which would closely follow and direct our life and the education of my child..."

A13. "I need education on how to impose limits on my child."

A12. "I would like to rapidly solve the problems that I encounter. Making him do his homework, making him study, what should I do when he does not listen to me, I would like to know."

\section{Discussion}

ADHD is labeled as the common problem of several disciplines. The leading of these disciplines are education, psychology and psychiatry. All interventions with ADHD children require the participation of family members. This study was conducted with the purpose of determining the stress level, quality of life and needs of parents and it found out that parents especially needed to be more knowledgeable about ADHD. In addition, it was determined that they had difficulty in explaining the specia situation of their children to other individuals in social life. Terzi and Cankaya (2006) reported that impulsivity concerning ADHD caused parents to experience difficulties in adapting to the community. Nuri (2017) stated that the type of inability of children could make a difference in the requirements of parents. One study conducted with the parents of children who receive inclusion education reported that parents mostly needed social support, information, assistance and adaptation (Tekinarslan, Sivrikaya, Keskin, Ozlu, \& Ucar-Rasmussen, 2018). The need for information is similar in both studies; however, it is seen that social support, assistance and adaptation needs represent difference when compared with the quantitative findings of the study. On the other hand, an examination of qualitative findings shows that, similar to the study conducted by Tekinarslan et al. (2018), it is found out that parents needed control over their children and helping them, that they demanded social support from their community due to inadequate support and that they needed financial assistance. Qualitative results displayed that parents felt themselves inadequate.

Impulsivity or destructive behaviors of children negatively affect the competence in the sense of parenting of parents (McLaughlin \& Harrison, 2006). Stress and quality of life also change depending on these emotions. Theule, Wiener, Tannock and Marton (2013) displayed that ADHD symptoms created intense stress on family members. Munoz-Silva, Lago-Urbano, Sanchez-Garcia and Carmona-Marquez (2017) revealed that social support perception affected the stress level of parents. Several studies showed that parents with ADHD children suffered from more stress compared to parents of children with normal development (Durukan et al., 2008; McCleary, 2002; Johnston \& Mash, 2001). In addition, it is reported that their quality of life is also lower (Xiang, Luk, \& Lai, 2009). The findings of this study are similar to the literature. It is ob- served that the stress level of parents who participated in the study is high whereas their family quality of life scores is low.

According to the results of the multiple regression analysis which was conducted within the framework of the objective of the study, it was seen that the family quality of life level predicted the perceived stress level of parents. It has been found out that $52 \%$ of the variance concerning stress perception could be explained with family quality of life. Individual examination for sub-dimensions showed that family interaction, emotional competence and support perception concerning incompetency were each predictors of the stress level (Nuri, Akcamete, \& Direktor, 2019). A study which was conducted on parents with autistic children displayed that, similar to the results of this research, perceived stress and social support critically predicted quality of life (Lu, Wang, Lei, Shi, \& Jiang, 2018; Nuri, Rustioglu, \& Piskin-Abidoglu, 2018, Nuri, Akcamete, \& Direktor, 2019).

In conclusion, it has been found out that parents with ADHD children needed information, social support and practical education which would support the acquisitions of the child. In addition, it is also concluded that high stress level affected the quality of life scores of parents in negative direction (Nuri, Akcamete, \& Direktor,2019). These findings indicated the necessity of devising family support programs which would increase the quality of life and decrease the stress level of parents taking their needs into consideration. The fact that the research was limited with parents of children with ADHD restrained the possibilities of making comparison with other education groups. However, the limitation of studies conducted with parents of children with ADHD increases the importance of the study in that it provides a vision concerning what these families go through. The obtained results showed that more studies should be conducted on the parents of children with ADHD and practical studies which reveal the difficulties of ADHD families in effective parenting or integrated education programs would make essential contribution to the field. In addition, it was recommended that programs should be devised to remedy the deficiencies in the supports given to families in the field of application which would be tested experimentally.

\section{References}

American Psychiatric Association. (2013). Diagnostic and statistical manual of mental disorders (DSM-5®). American Psychiatric Pub.

Aydın, C. \& Ercan, E.S. (2005). Dikkat Eksikligi Hiperaktivite Bozuklugu Ozellikleri- Tedavisi Çocuklarda ve Eriskinlerdeki Belirtileri. (Genisletilmis 12. Baskı). İstanbul: Gendas Kultur.

Aysan, F., \& Ozben, S. (2007). Engelli çocugu olan anne babaların yasam kalitesine iliskin degiskenlerin incelenmesi. Dokuz Eylul Universitesi, Buca Egitim Fakultesi Dergisi, 22, (1 - 6).

Cavkaytar, A., Ardıc, A., \& Aksoy, V. (2014). Aile gereksinimlerini belirleme aracının geçerlik ve guvenirliginin guncellenmesi. Ankara Universitesi Egitim Bilimleri Fakultesi Ozel Egitim Dergisi, 15(2), 1-12.

Cavkaytar, A., Batu, S., Kartal, B., Beklan-Çetin, O. \& Gullupınar, F. (2004). Gelisimsel yetersizlige sahip ailelerin aile ozelliklerinin ve yasadıklarının betimlenmesi. Eskisehir, Turkey: Anadolu Universitesi Yayınları. 
Cohen, S., Kamarck, T., \& Mermelstein, R. (1983). A global measure of perceived stress. Journal of Health and Social Behavior, 385-396.

Dalbudak, E., Evren, C., Evren, B., \& Ozen, S. (2017). Relationship of severity of ADHD symptoms with the presence of psychological trauma while controlling the effect of impulsivity in a sample of university students. European Psychiatry, 41, 134.

Daley, D., Jones, K., Hutchings, J., \& Thompson, M. (2009). Attention deficit hyperactivity disorder in preschool children: current findings, recommended interventions and future directions. Child: care, health and development, 35(6), 754-766.

Davies, W. (2014). Sex differences in attention deficit hyperactivity disorder: candidate genetic and endocrine mechanisms. Frontiers in Neuroendocrinology, 35(3), 331-346.

Durukan, I., Erdem, M., Tufan, A. E., Congologlu, A., Yorbık, O. \& Turkbay, T. (2008). DEHB olan çocukların annelerinde depresyon ve anksiyete duzeyleri ile kullanılan basa çıkma yontemleri: Bir ön çalışma. Anadolu Psikiyatri Dergisi, 9, 217-223.

Eskin, M., Harlak, H., Demirkıran, F., \& Dereboy, Ç. (2013). Algılanan stres olçeginin Turkçeye uyarlanması: guvenirlik ve geçerlik analizi. New/Yeni Symposium Journal, 51(3), 132-140).

Feldman, M. A., \& Werner, S. E. (2002). Collateral effects of behavioral parent training on families of children with developmental disabilities and behavior disorders. Behavioral Interventions: Theory \& Practice in Residential \& Community-Based Clinical Programs, 17(2), 75-83.

Fischer, M, (1990). Parenting Stres and the Child With Attention Deficit Hyperactivity Disorder. Journal of Clinical Child Psychology, 19(4), 337-346.

Gallo, E. F., \& Posner, J. (2016). Moving towards causality in attention-deficit hyperactivity disorder: overview of neural and genetic mechanisms. The Lancet Psychiatry, 3(6), 555-567.

Geissler, J., \& Lesch, K. P. (2011). A lifetime of attention-deficit/hyperactivity disorder: diagnostic challenges, treatment and neurobiological mechanisms. Expert Review of Neurotherapeutics, 11(10), 1467-1484.

Harpin, V. A. (2005). The effect of ADHD on the life of an individual, their family, and community from preschool to adult life. Archives of Disease in Childhood, 90, i2-i7.

Hoffman, L., Marquis, J., Poston, D., Summers, J. A., \& Turnbull, A. (2006). Assessing family outcomes: psychometric evaluation of the Beach Center Family Quality of Life Scale. Journal of Marriage and Family, 68(4), 1069-1083.

Johnson, R. B., \& Christensen, L. B. (2004). Educational research: Quantitative, qualitative, and mixed approaches. Boston, MA: Allyn and Bacon.

Johnston, C., \& Mash, E. J. (2001). Families of children with attention-deficit/hyperactivity disorder: review and recommendations for future research. Clinical Child and Family Psychology Review, 4(3), 183-207.
Kose, E. (2010). Bilimsel Arastırma Modelleri. R. Y. Kıncal (Ed.), Bilimsel Arastırma Yontemleri (s.97-119). Ankara: Nobel Yayın Dagıtım.

Lu, M. H., Wang, G. H., Lei, H., Shi, M. L., Zhu, R., \& Jiang, F. (2018). Social Support as Mediator and Moderator of the Relationship Between Parenting Stress and Life Satisfaction Among the Chinese Parents of Children with ASD. Journal of Autism and Developmental Disorders, 48(4), 1181-1188.

Mccleary, L. (2002). Parenting Adolescents With Attention Deficit Hyperactivity Disorder: Analysis Of The Literature For Social Work Practice. Health and Social Work, 27(4), 285-292.

Mclaughlin, D.P. \& Harrison, C.A. (2006). Parenting Practices of Mothers of Children With ADHD: The Role of Maternal and Child Factors. Child and Adolescent Mental Health, 11(2), 82-88.

Meral, B. F., \& Cavkaytar, A. (2013). Beach center aile yasam kalitesi olçegi'nin turkçe uyarlama, geçerlik ve guvenirlik çalısması. Egitim ve Bilim, 38, 170.

Muñoz-Silva, A., Lago-Urbano, R., Sanchez-Garcia, M., \& Carmona-Márquez, J. (2017). Child/adolescent's ADHD and parenting stress: The mediating role of family impact and conduct problems. Frontiers in Psychology, 8, 2252.

Natale, K., \& Lubniewski, K. (2018). Use of communication and technology among educational professionals and families. International Electronic Journal of Elementary Education, 10(3), 377-384.

Nuri, C. (2017). Dikkat eksikligi ve hiperaktivite bozuklugunda aile içi sorunlar ve ozel egitim destegi. In: Akfirat, N.O., Staub, D.F. \& Yavas, G., (Eds.), Current Debates in Education (Vol. 5.1). Istanbul: IJOPEC Publication.

Nuri, C., Rustioglu, O., \& Piskin-Abidoglu, U. (2018). The problems of the families who have autistic children: A qualitative research. Life Skills Journal of Psychology, 2(3), 97-111.

Nuri, C., Akçamete, G., \& Direktor, C. (2019). The Quality of Life and Stress Levels in Parents of Children with Attention Deficit Hyperactivity Disorder. European Journal of Special Education Research, 4(3), 27-40.

Ozerk, M., Handorff, J. A., \& Ozerk, K. (2017). Assessment of bilingual children with inattention, over activity and impulsivity-Challenges and solutions. International Electronic Journal of Elementary Education, 3(3), 193-212.

Park, J., Hoffman, L., Marquis, J., Turnbull, A. P., Poston, D., Mannan, H., ... \& Nelson, L. L. (2003). Toward assessing family outcomes of service delivery: Validation of a family quality of life survey. Journal of Intellectual Disability Research, 47(4-5), 367-384.

Polanczyk, G., De Lima, M. S., Horta, B. L., Biederman, J., \& Rohde, L. A. (2007). The worldwide prevalence of ADHD: a systematic review and metaregression analysis. American Journal of Psychiatry, 164(6), 942948.

Schalock, R. L., \& Verdugo-Alonso, M. A. (2002). Handbook on quality of life for human service practitioners. Washington, DC: American Association on Mental Retardation. 
Seltzer, M., Floyd, F., \& Hindes, A. (2004). Research methods in intellectual disabilities: The family context. In E. Emerson, C. Hatton, T. Thompson \& T. R. Parmenter (Eds.), The International Handbook of Applied Research inIntellectual Disabilities (pp. 237260). West Sussex, England: John Wiley \& Sons.

Simon, V., Czobor, P., Bálint, S., Mészáros, A., \& Bitter, I. (2009). Prevalence and correlates of adult attention-deficit hyperactivity disorder: meta-analysis. The British Journal of Psychiatry, 194(3), 204-211.

Spencer, T. J., Biederman, J., \& Mick, E. (2007). Attention-deficit/hyperactivity disorder: diagnosis, lifespan, comorbidities and neurobiology. Journal of pediatric psychology, 32(6), 631-642.

Senol, S., İseri, E. \& Koçkar-Ilden, A, (2005). Dikkat Eksikligi Hiperaktivite Bozuklugu Dikkati Dagınık, Yerinde Duramayan Çocuklara Dogru Yaklasımlar. Ankara: HYB Yayıncılık.

Tekinarslan, I. C., Sivrikaya, T., Keskin, N. K., Ozlu, O., \& Rasmussen, M. U. (2018). Kaynastırma egitimi alan ogrencilerin ebeveynlerinin gereksinimlerinin belirlenmesi. Ilkogretim Online, 17(1).

Terzi, S., \& Cankaya, Z. C. (2009). Baglanma stillerinin oznel iyi olmayı ve stresle basa çıkma tutumlarını yordama gucu. Turk Psikolojik Danısma ve Rehberlik Dergisi, 4(31), 1-11.

Theule, J., Wiener, J., Tannock, R. \& Marton, I. (2013). Predicting parenting stress in families of children with ADHD: parent and contextual factors. Journal of Child and Family Studies, 20(5), 640-647.

Turnbull, A. P., Turbiville, V., \& Turnbull, H. R. (2000). Evolution of family-professional partnerships: Collective empowerment as the model for the early twenty-first century. Early Childhood Intervention, 2, 630-650.

Willcutt, E. G. (2012). The prevalence of DSM-IV attention-deficit/hyperactivity disorder: a meta-analytic review. Neurotherapeutics, 9(3), 490-499.

Xiang, Y., Luk-Ernest, S. L. \& Lai-Kelly, Y.C, (2009). Quality of Life In Parents of Children With Attention Deficit Hyperactivity Disorder In Hong Kong. The Royal Australian New Zealand College of Psychiatrist, 43, 731-738. 